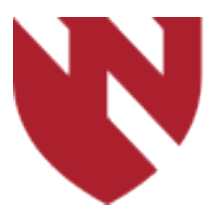

September 2020

\title{
How Many Emergency Medicine Rotations Are Students Completing?
}

\author{
Erin Karl \\ University of Nebraska Medical Center \\ Chichen Qiu \\ Stanford University \\ Zach Jarou \\ University of Chicago
}

Tell us how you used this information in this short survey.

Follow this and additional works at: https://digitalcommons.unmc.edu/gmerj

Part of the Higher Education Commons, and the Medicine and Health Sciences Commons

\section{Recommended Citation}

Karl, E., Qiu, C., , Jarou, Z. How Many Emergency Medicine Rotations Are Students Completing?. Graduate Medical Education Research Journal. 2020 Sep 29; 2(1).

https://digitalcommons.unmc.edu/gmerj/vol2/iss1/21

This Conference Proceeding is brought to you for free and open access by DigitalCommons@UNMC. It has been accepted for inclusion in Graduate Medical Education Research Journal by an authorized editor of DigitalCommons@UNMC.For more information, please contact digitalcommons@unmc.edu. 
How Many Emergency Medicine Rotations Are Students Completing?

Creative Commons License

(c) (i) (9)

This work is licensed under a Creative Commons Attribution-Noncommercial-No Derivative Works 4.0 License. 


\section{How Many Emergency Medicine Rotations Are Students Completing?}

Chichen Qiu', Erin Karl'2, Zach Jarou ${ }^{3}$

${ }^{1}$ Stanford University, Department of Emergency Medicine, Stanford, CA

2University of Nebraska Medical Center, Department of Emergency Medicine

${ }^{3}$ University of Chicago, Section of Emergency Medicine, Chicago, IL

Program: Emergency Medicine

Type: Original Research

Background: The CORD Advising Students Committee in Emergency Medicine (ASCEM) recommends EM-bound medical students complete two EM clerkships. In recent years, the number of VSAS applications per applicant has increased, leading to increased demand for rotation slots.

Methods: Fourth-year medical students $(\mathrm{n}=132)$ attending the Emergency Medicine Residents' Association Medical Student Forum at the 2018 Scientific Assembly were asked to complete a 24 question survey. Response rate was $80.2 \%$. Students who were IMGs, couples or military matching, had not taken Step 1, or had not completed or received their grade from at least one EM rotation were excluded (leaving $\mathrm{n}=72$ ). Descriptive, summary statistics were used.

Results: The mean number of EM rotations scheduled was 3.30. The mean for MD and DO students was 2.93 (95\% CI 2.75-3.11) and 3.82 (95\% CI 3.57-4.07), respectively. Figure 1 shows that $15 \%$ of allopathic students limited themselves to two EM clerkships, compared to $0 \%$ of osteopathic students. The

\section{Number of EM Rotations Students Have Scheduled During Fourth Year} DO $\square \mathrm{MD}$

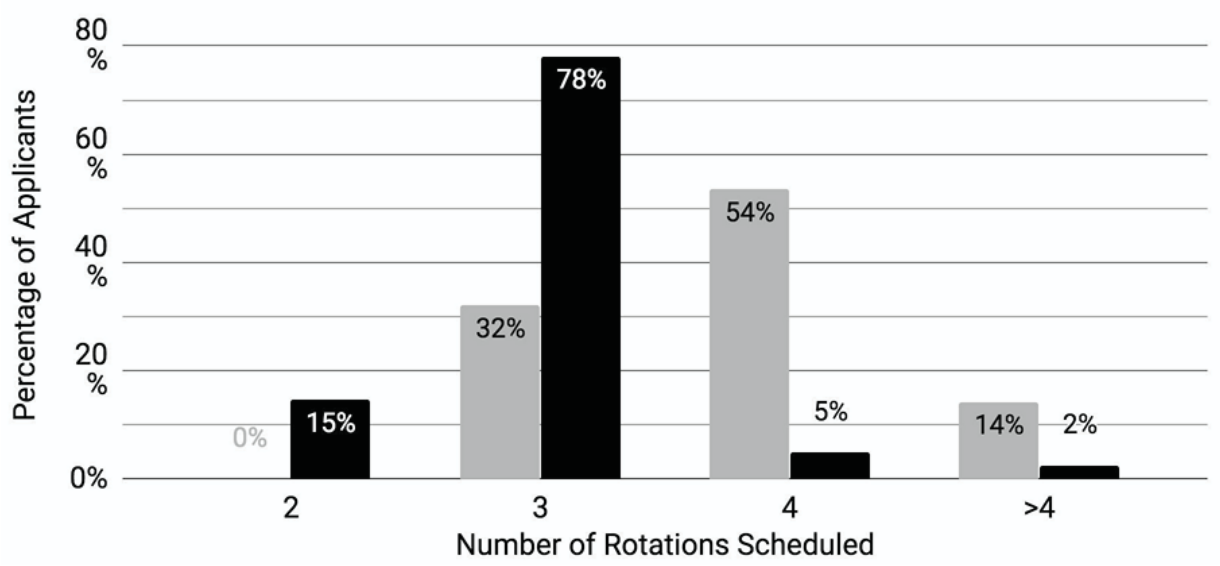

Figure 1. Number of EM rotations medical students have scheduled during their fourth year. $(n=72)$

most frequently reported number of clerkships for MD applicants was three. More than two-thirds $(68 \%)$ of DO applicants scheduled four or more rotations, compared to only $7 \%$ of MD applicants. There was no statistical difference in the mean number of clerkships scheduled when groups were broken down by self-rating of competitiveness $(p=0.712)$, confidence in evaluating self-competitiveness $(\mathrm{p}=0.553)$, or by step 1 score ranges $(\mathrm{p}=0.728)$. Means were compared with t-test and one way ANOVA.

Conclusions: The students in our sample scheduled more than two EM clerkships, with DO applicants completing more rotations than MD applicants.

https://doi.org/10.32873/unmc.dc.gmerj.2.1.020

\section{Total Motile Sperm Count Effect on Pregnancy Outcomes in Intrauterine Insemination} Melissa Mathes ${ }^{1}$, Stephanie Gustin ${ }^{1,2}$

${ }^{1}$ University of Nebraska Medical Center, Department of Obstetrics and Gynecology

${ }^{2}$ Heartland Center for Reproductive Medicine, Omaha, NE

Mentor: Stephanie L Gustin

Program: Obstetrics and Gynecology

Type: Original Research

Background: Intrauterine insemination (IUI) is a frequently used method to treat couples with infertility. There is evidence of decreased pregnancy rates with total motile sperm count (TMSC) less than 5 and 10 million $(1,2)$, yet there has been efficacy of reported IUI success with TMSC under 1 million (2). As such, there remains to be a consensus on semen parameters for which to recommend IUI in the infertile population.

Methods: This is a retrospective cohort study of all IUI cycles at an infertility center from June 2014 to May 2018. We obtained female characteristics including age, gravida, parity, and number of dominant follicles. The following semen parameters were collected: post wash TMSC, concentration, motility, and wet mount morphology. Our primary outcome of interest was the presence or absence of serum and clinical pregnancy after each cycle Serum pregnancy was defined as an elevation of serum beta-human chorionic gonadotropin and clinical pregnancy by fetal cardiac activity on ultrasound.

Results: A total of 1052 women underwent 2180 IUI cycles during this four-year period. The overall clinical pregnancy rate was $19.8 \%$ per cycle. There was an increase in cycle fecundity with increasing TMSC, OR 0.46 for TMSC $\leq 1 \mathrm{M}, 0.64$ for TMSC $2-5 \mathrm{M}$, and 0.85 for TMSC $6-10 \mathrm{M}$, compared to TMSC $>10 \mathrm{M}$. Using receiver operating characteristic curves, we did not identify a TMSC threshold to offer IUI.
Conclusion: Although no distinct threshold of TMSC was identified to offer IUI versus a more aggressive therapy, there is a positive correlation between TMSC and IUI success.

https://doi.org/10.32873/unmc.dc.gmerj.2.1.021

\section{References}

1 Van Voorhis BJ, Barnett m, Sparks AE, Syrop CH, Rosenthal G, Dawson J. Effect of the total motile sperm count on the efficacy and cost-effectiveness of intrauterine insemination and in vitro fertilization Fertil Steril. 2001;75:661-8

2 Merviel P, Heraud MH, Grenier N, Lourdel E, Sanguinet $\mathrm{P}$, Copin H. Predictive factors of pregnancy after intrauterine insemination (IUI): An analysis of 1038 cycles and a review of the literature. Fertil Steril. 2010;93:79-88 